\title{
Introduktion til seks artikler uden for tema
}

\section{AF MICHAEL BRUUN ANDERSEN}

Mens første del af dette nummer af Journalistica har mediernes økonomiske dimensioner som tema, er nummerets sidste fire artikler tæt på journalistikken og dens tilblivelse. De fire artikler har alle sit udspring i forskningsmiljøet omkring journalistuddannelsen på Roskilde universitet.

I artiklen Print- og netaviser i Danmark, USA og Frankrig sammenligner Mark Blach-Ørsten og Ida Willig tre danske papiraviser (Berlingske Tidende, Jyllands-Posten og Politiken) med deres modsvarende netaviser. Følgende indholdsdimensioner sammenlignes: Fordelingen af nyheder, opinion og debat; udlandsstof, indlandsstof ("regering"), krimstof og bløde nyheder; mængden af annoncer. Analysen af de danske medier viser, at der er færre annoncer på nettet end i papiraviserne. Her skal man være opmærksom på, at analysen baserer sig på tal fra 2008, og som forfatterne siger, er 4-5 år længe på dette område, selv om forsøgene med at oprette betalingsmure viser, at netaviserne stadig ikke er nogen god forretning i 2013.

Analysen viser videre, at netaviserne har flere bløde nyheder end de tilsvarende papirudgaver, mindre udenrigsstof, mindre indenrigsstof og lidt mere krim. Ordet tabloidisering bliver ikke brugt i artiklen, men karakteristikken ligger lige for. Endelig er der spørgsmålet om forholdet mellem nyheder, kommentarer og debat. Her er forskellen ubetydelig, dog således at der er flere nyheder på nettet end på papiravisen. Forfatterne konkluderer, at forskellen mellem papir- og netaviser er beskeden, dog således, at mixet er lidt anderledes til fordel for nyhedsgenren.

Dette er imidlertid kun den ene dimension i analysen. Den internationale analyse skal på den ene side vise eventuelle lighe- 
der og forskelle på de tre analyserede lande, men også forsøge at sige noget om Hallin og Mancinis konvergenshypotese, nemlig at mediesystemerne i de tre lande er forskellige, men bliver stadig mindre forskellige på grund af kommercialiseringen. En række undersøgelser har udfordret denne hypotese især hvad angår de gamle medier, og forfatterne konkluderer forsigtigt, at tesen måske har mere for sig når det drejer sig om netaviser, men at der må flere analyser til.

Blach-Ørstens og Willigs studie viser, at der i hvert fald i Danmark er ret store ligheder mellem papiraviser og netaviserne, men at der også er forskelle. Hvad er baggrunden for dette? Aviserne produceres af de samme mediehuse, men måske skyldes både ligheder og forskelle den måde mediehusene organiserer nyhedsproduktionen på. Dette kan siges at være emnet for artiklen 'Lillebror-syndromet'. Nye hierakier i den tvarmediale nyhedsproduktion af Jannie Møller Hartley. Tre forskellige mediehuse er studeret, nemlig regionsavisen Nordjyske (nordjyske.dk), landsavisen Politiken (politiken.dk) og public service-institutionen DR (dr.dk). De tre huse har organiseret samarbejdet mellem dem der producerer til nettet og dem som producerer til papir på forskellig måde. Forfatteren beskriver de forskellige organiseringer som et kontinuum, hvor der i den ene ende er mere eller mindre selvstændige netredaktioner (politiken.dk)og i den anden ende netredaktioner, som er mere eller mindre integrerede med papirredaktionen (nordjyske.dk). Et vigtigt fund er, at jo mere integreret netredaktionen er desto mere kommer den til at fungere som er 'serviceorgan': Den får en distribuerende rolle over for papirredaktionens hovedsageligt producerende rolle. Dermed bliver netjournalisterne placeret på en ny måde i det interne hierarki, nemlig nederst, som lillebror. 'Lillebror-syndromet' er forfatterens betegnelse for journalisternes oplevelse af den nye placering på den anden side af en usynlig mur, som tendentielt deler de ansatte i et A- og et B-hold. En kamp om anerkendelse kan forudses, en kamp vi ikke ved hvem der vinder. Med papirmediernes stadig svagere oplag og økonomi synes resultatet på lidt længere sigt givet, men i mellemtiden kan opdelingen i stjerner og vandbærere have sedimenteret sig til ugunst for indholdet i de gradvist dominerende netaviser. Hvordan sammenhængen mellem de nye måder mediekoncernerne vælger at bruge arbejds- 
kraften på og det journalistiske indhold er ikke artiklens ærinde. Koblingen mellem journalistiske produktionsmåder og redskaber og det journalistiske indhold, som tilbydes læsere, lyttere og seere er fundamental. Også her genstår megen forskning.

Journalistikkens fundamentalredskab er sproget, i Danmark det danske sprog. Man kan undre sig over at analyser af dette redskab er om ikke helt fraværende, så dog noget stedmoderligt behandlet i journalistikforskningen. Dette står i modsætning til den interesse der blandt mange læsere er for 'godt sprog', ordentlig stavemåde osv. På redaktionerne er der også interesse for 'godt og levende og korrekt sprog i journalistikken', men disse ambitioner synes at komme til kort over for kravet om hurtighed i nyhedsformidlingen, hvilket tydeligt ses på netaviserne. Viljen til at betale for sprogkvalitet er vigende. Der er ikke mange korrekturlæsere tilbage, de synes erstattet af tekstbehandlingsprogrammernes stavekontrol.

I Leif Becker Jensens artikel Den journalistiske automatskrift drejer det sig imidlertid om noget andet, nemlig om journalistiske normer på det sproglige område. Normer og rutiner er nødvendige ikke mindst i nyhedsjournalistikken, hvor hastighed og produktionstempo er højt, og hvor et mere kunstfærdigt sprog, hverken er muligt eller ønskeligt. De sproglige normer Becker Jensen analyserer indlæres på journalistuddannelserne og i praktikperioden på redaktionerne og kommer naturligvis til udtryk i journalistikken selv. Men som eksplicitte normer er det enklest at finde dem i lærebøger i journalistik. Men hvilken norm er der tale om? I artiklen bruges (forbudet mod) anvendelsen af passiv som eksempel. "Agensstrygning" er ikke alene manipulativ, men også uforståelig.

Artiklens ærinde er at beskrive denne norm, herunder dens sprogvidenskabelige rødder, men også at drøfte betimeligheden af sådanne normer. Artiklens standpunkt er, at brug af passiv meget vel kan være funktionel, at det med andre ord kan være nyttigt at bruge passiv afhængigt af den konkrete anvendelse. Dermed kommer journalistiklæreren i et klassisk dilemma: Skal man først sørge for at journalisteleverne lærer de gældende normer, så de kan praktisere dem, og derefter kritisere dem med fare for, at kritikken ikke får effekt? Hvad der tydeligvis mangler, er mere videnskabeligt baseret kundskab om netop den funktio- 
nelle dimension, en kundskab, som kan supplere den delvis på journalistisk erfaring delvis sprogvidenskabeligt legitimerede norm. 'Passiv-forbudet' har vist sig standhaftigt, men i lyset af mediebrugernes bedre uddannelse, ændrede medie- og sprogvaner er det ikke sikkert at journalistuddannelserne skal forlænge sådanne i hvert fald delvis 'dysfunktionelle' normer.

Det ligger lige for i forlængelse af Becker Jensens nuancerede kritik af normen at spørge, hvordan i dette tilfælde journalistiske normer ændres, forandrer sig, og på hvilken måde de redaktionelle ledere bidrager til ændringer eller udøver modstand mod dem. Som både Black-Ørsten og Willig og Møller Hartley er inde på fra forskellige vinkler, så er der i den journalistiske institution stærke, traderede værdier og inerti både organisatorisk og indholdsmæssigt herunder sprogligt, som Becker Jensen viser. I en tid hvor forandringens vinde blæser stærkere end længe i medieverdenen er et naturlig spørgsmål: Bliver de da aldrig klogere? Hvordan opsamler man erfaringer og bliver klogere? Dette er emnet for den sidste artikel i dette nummer af Journalistica.

I en lille 'pilotundersøgelse' spørger Hanne Jørndrup og Niels Rohleder i artiklen Krigsredaktører. Danske udlandsredaktørers erfaringer med krigsjournalistik en række redaktører (DR, Berlingske, Ekstra Bladet og Information), hvad de har lært af dækningen af de seneste års krige Danmark har deltaget i. Spørgsmålene, som redaktørerne blev stillet i 2011 var organiseret i fire temaer: Hvilke krige skal dækkes og hvordan? Hvilke personer skal sendes ud og hvem kan der samarbejdes med? Svarene er meget forskelligartede beroende på mediernes forskellige ressourcer og placering i mediebilledet. Selvkritikken er som forventet ikke dominerende. På det vigtige spørgsmål om den nationalt begrundede selektion og vinkling er svarene modsætningsfyldte. Også synet på forsvaret som kilde viser modsætninger, som udspringer af behovet for kilder og mangelen på indsigtsfulde alternative kilder. Konkurrencen mellem medierne gør det videre vanskeligt at lægge et fælles pres på sådanne autoritative kilder for mere åbenhed og mulighed for at komme uden om spinmaskinen.

Videndelingen inden for den enkelte medieorganisation synes god, mens erfaringsopsamlingen ser ud til at være meget afhængig af organisationens ressourcer. På information var der en ten- 
dens til at man starter forfra hver gang. Undersøgelsens fokus på redaktørlaget rejser spørgsmålet om erfaringsopsamling på ledelsesplan. Dette kan i forlængelse af artiklens empiriske fokus benævnes teoretisk som spørgsmålet om eller hvordan journalistiske institutioner fungerer som lærende organisationer. Er de i stand til at forandre og korrigere en praksis med stærk inerti på basis af egne erfaringer eller læring? Undersøgelsen synes at vise, at eventuelle læringssammenhænge opløser sig i journalistikkens praktiske enkeltelementer og problemer forbundet hermed. Dette gør det vanskeligt at få øje på de overordnede problemer med dækningen. Her kan man tænke på de problemer som den såkaldte index-teori har demonstreret, nemlig at begivenheder af national betydning som fx krige kun får kritisk dækning, hvis de politiske kilder giver mulighed for det. Hvis politikerne er enige eller ikke vil sige noget, er der ingen konflikter, og i en sådan situation bliver medierne blot et spejl af denne situation, de bliver megafoner for den nationale dagsorden i stedet for kritiske overvågere af statsmagten til skade for befolkningens oplysning og selvstændige stillingstagen. Skal man tro de interviewede redaktører ser det ikke ud til at de til fulde har forstået disse strukturelle forhold, måske fordi de er baseret på journalistiske normer og rutiner. At få øje på egne briller er ikke let. Det er jo dem man ser med. Der i ligger udfordringen for læringen.

\section{Redaktionel kommentar fra ansvarshavende redaktør Roger Buch:}

Ud over de fire artikler, hvor Michael Bruun Andersen har koordineret bedømmelserne, er der yderligere to artikler, som har været igennem Journalisticas normale bedømmelsesproces:

JENS E. KJELDSEN OCH GUNNAR NYGREN:

Planerad och iscensatt fotojournalistik

\section{HANNE BRUUN:}

Det politiske talkshow og dets publikum 